\title{
4,5,12,13-Tetrabromo[2.2]paracyclophane - A New Bis(aryne) Equivalent
}

\author{
Burkhard König ${ }^{1 \neq 1}$, Burkhard Knieriem, Karsten Rauch, and Armin de Meijere* \\ Institut für Organische Chemie, Universität Göttingen, \\ Tammannstraße 2, 37077 Göttingen, F.R.G. \\ Received April 2, 1993 \\ Key Words: [2.2]Paracyclophanes / 1,2-Dibromoarenes / anti-[2.2]Paracyclophanes / Aryne generation / \\ Diels-Alder reactions
}

The reaction of 2 with $n \mathrm{BuLi}$ at $-78^{\circ} \mathrm{C}$ generates aryne intermediates within the aromatic rings of [2.2]paracyclophane which are trapped in Diels-Alder reactions with dienes like furan, 1,9-diphenylisobenzofuran, or cyclopentadiene. Reductive deoxygenation with low-valent titanium reagents or TMSI converts the adducts of furan and isobenzofuran into anti-[2.2]paracyclophanes 4 and 5, respectively. The reaction of two aryne intermediates with $[2.2](2,5)$ furanophane (7) yields 8 with three [2.2]paracyclophane units arranged in a stair-like fashion $_{i}$ yet, in this compound the highly shielded oxygen atoms cannot be removed anymore by reduction.
One of the most useful synthetic methods of generating aryne intermediates is the treatment of 1,2-dibromoarenes with $n \mathrm{BuLi}$ at low temperature ${ }^{[1]}$. By trapping the strained intermediate with suitable dienes, a variety of benzo-anellated bi-, tri-, or oligocyclic skeletons are available in moderate to excellent yields.

We have recently reported on the facile synthesis of 4,5,12,13-tetrabromo[2.2]paracyclophane $(2)^{[2]}$. As shown by $\mathrm{X}$-ray structure analysis, the two dibromobenzene units in $\mathbf{2}$ are rigidly held in a parallel orientation like the benzene rings in the parent skeleton of [2.2] paracyclophane ${ }^{[3]}$, but slightly displaced with respect to each other, as the torsion angle of $14^{\circ}$ in the ethano bridges indicates ${ }^{[2]}$. Like $1,2,4,5-$ tetrabromobenzene (1), which can be used as a bis(dehydrobenzene) precursor ${ }^{[4]}, 2$ ought to be considered a bis(aryne) precursor $^{[5]}$, in which the two 1,2-dibromobenzene units are held apart by the ethano bridges, but strongly interact electronically through the $\sigma$ bonds $^{[6]}$. Tetrabromide 2 can therefore be considered a 1,2,4,5-tetrabromobenzene extended into the third dimension.<smiles>Brc1cc(Br)c(Br)cc1Br</smiles>

1

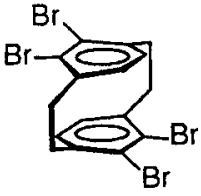

2
Indeed, by treatment of a solution of 2 in THF with 2.1 equiv. of $n \mathrm{BuLi}$ in the presence of furan at $-30^{\circ} \mathrm{C}$, the two isomeric syn,syn and anti,syn cycloadducts 3 are obtained in 12 and $15 \%$ yield, respectively ${ }^{[* !}$. Formation of the anti,anti isomer has not been observed. The geometry of the syn,syn

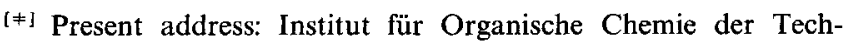
nischen Universität Braunschweig, Hagenring 30, 38106 Braunschweig, F.R.G.

[*] The stereochemical descriptors syn and anti refer to the orientation of the oxygen bridge in the oxabicyclo[2.2.1] heptadiene subunit with respect to the [2.2]paracyclophane skeleton.

product has been proved by X-ray crystal structure analysis (Figure 1) ${ }^{[7]}$. Bond distances and angles in both the [2.2]paracyclophane and 7-oxanorbornadiene moieties of syn,syn-3 are quite normal, and so is the out-of-plane bending of the para-bridged benzene rings (see Figure 1). The bonds $C(4)-C(5)$ and $C(9)-C(8)$ (and the corresponding ones on the other side of the molecule) are bent by $2.7^{\circ}$ inward towards the second benzene ring, corresponding to the known altered hybridization of the benzene carbon atoms towards $\mathrm{sp}^{3}$ in out-of-plane-bent aromatic rings like those in [2.2] paracyclophane ${ }^{[8]}$. The two benzene decks in syn,syn-3 are slightly shifted apart causing a twist in the two-carbon bridges between them [dihedral angle $\mathrm{C}(3)-\mathrm{C}(2)$ C(1)-C(10a) $\left.9.2^{\circ}\right]$.
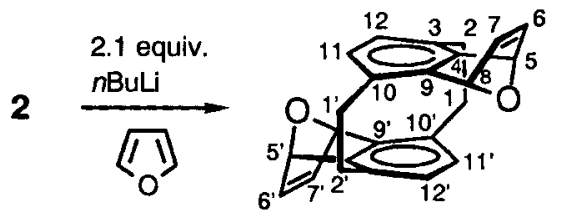

syn,syn-3

$$
\begin{aligned}
& \mathrm{TiCl}_{4}, \mathrm{LiAlH}_{4}, \\
& \frac{\mathrm{NEt}_{3}, \text { room temp. }}{\text { THF }}
\end{aligned}
$$

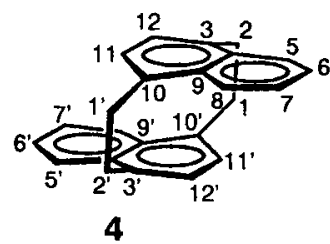

Upon reductive deoxygenation with low-valent titanium reagents ${ }^{[9]}$, both isomers syn,syn- and anti,syn-3 yield the known anti-[2.2]naphthalenophane $4^{[10]}$ in $69 \%$ yield. The same product is obtained by catalytic hydrogenation of $\mathbf{3}$ and acidic workup.

The aryne intermediate from $\mathbf{2}$ is trapped more efficiently by 2,5-diphenylisobenzofuran to lead to a mixture of syn,syn and anti,syn cycloadducts in 33 and $25 \%$ yield, respectively. The bridging oxygen atoms in these adducts are inert to- 


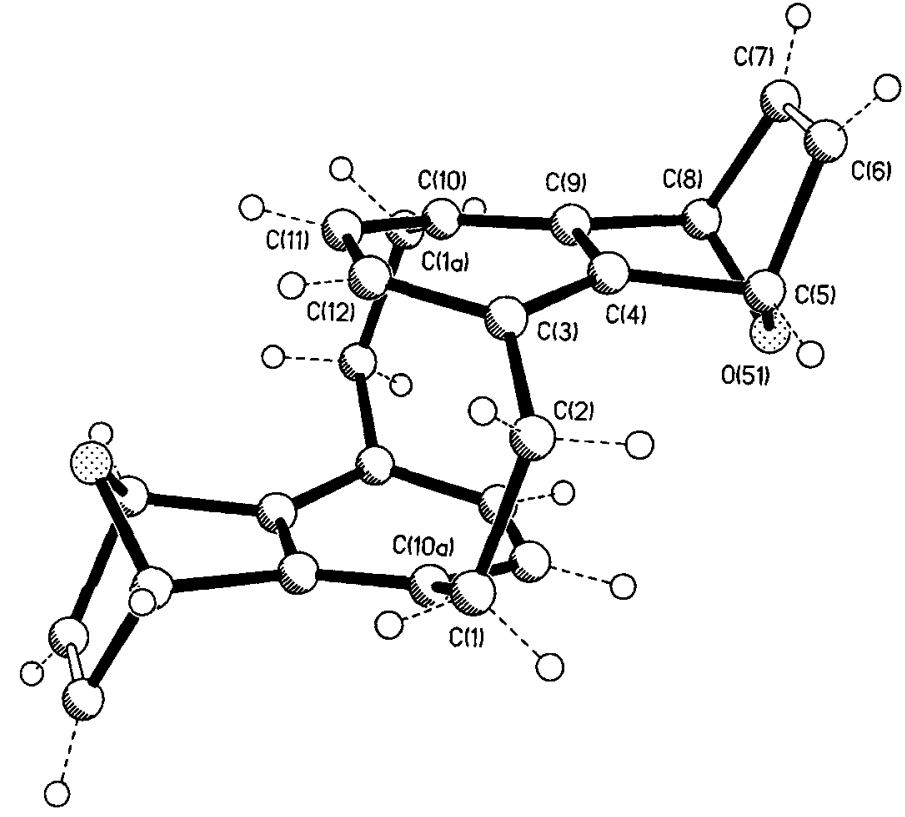

Figure 1. Molecular structure of $5,5^{\prime}, 8,8^{\prime}$-tetrahydro-syn,syn$5,8: 5^{\prime}, 8^{\prime}$-diepoxy-anti-[2.2](1,4)naphthalenophane (syn,syn-3); selected dihedral angle and interplanar angles $\left[{ }^{\circ}\right]: C(3)-C(2)-C(1)-$ $\mathrm{C}(10 \mathrm{a}) \quad 9.2 ; \mathrm{C}(12)-\mathrm{C}(3)-\mathrm{C}(4) / \mathrm{C}(4)-\mathrm{C}(9)-\mathrm{C}(11)-\mathrm{C}(12) 11.8, \mathrm{C}(9)-$ $\mathrm{C}(10)-\mathrm{C}(11) / \mathrm{C}(4)-\mathrm{C}(9)-\mathrm{C}(11)-\mathrm{C}(12) \quad 12.1, \mathrm{C}(4)-\mathrm{C}(5)-\mathrm{C}(8)-\mathrm{C}(9)$ $\mathrm{C}(5)-\mathrm{C}(6)-\mathrm{C}(7)-\mathrm{C}(8) \quad 111.0, \mathrm{C}(4)-\mathrm{C}(9)-\mathrm{C}(11)-\mathrm{C}(12) / \mathrm{C}(4)-\mathrm{C}(5)-$ C(8)-C(9) 2.7

wards reductive removal with low-valent titanium reagents. A successful, stepwise deoxygenation to $9,9^{\prime}, 10,10^{\prime}$-tetraphenyl-anti-[2.2](1,4)anthracenophane $\mathbf{5}$, however, is achieved by treatment with in situ generated trimethylsilyl iodide $^{[11]}$.

Even cyclopentadiene is a suitable diene to trap the bis(aryne) intermediate from 2 . When generated in the presence of 2, a mixture of nearly equal amounts of the syn,syn and

2

1) 2.1 equiv. $n B u L i$
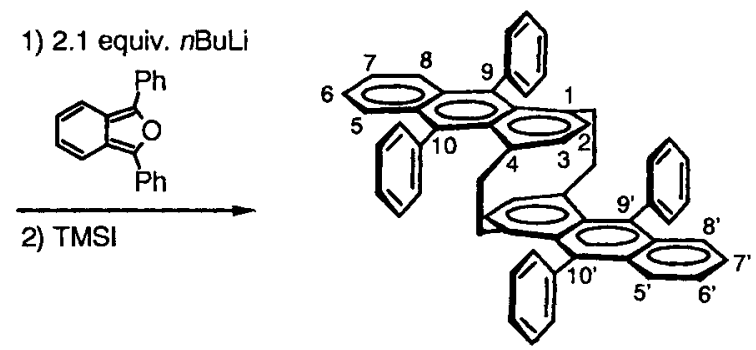

5

2
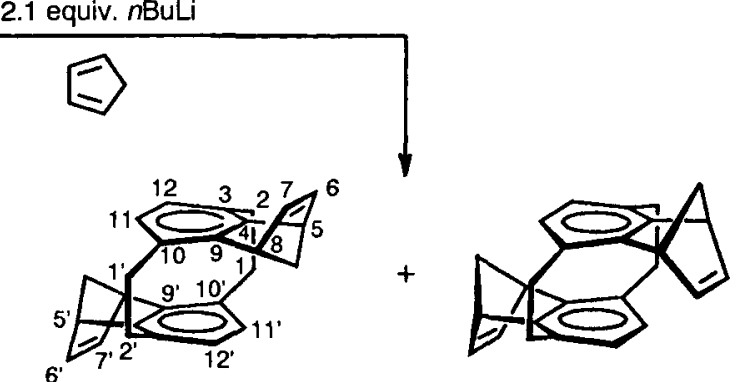

syn,syn-6

anti,syn-6 anti,syn cycloadducts 6 is obtained in $45 \%$ yield and characterized by its ${ }^{1} \mathrm{H}$ NMR spectrum.

By treatment of 2 with 1.0 equiv. of $n \mathrm{BuLi}$, only one of the two 1,2-dibromobenzene moieties reacts, whereas the second one remains unchanged. Thus, when 2.0 equiv. of 2 are treated with 2.0 equiv. of $n \mathrm{BuLi}$ in the presence of [2.2]furanophane (7) ${ }^{[12]}$ as the trapping agent, only a single product is obtained. Its constitution has been derived from spectroscopic data to be 8, in which three [2.2]paracyclophane units are connected in a stair-like fashion. Unfortunately, all attempts to remove the shielded oxygen atoms from 8 in order to aromatize the two central rings, have failed.

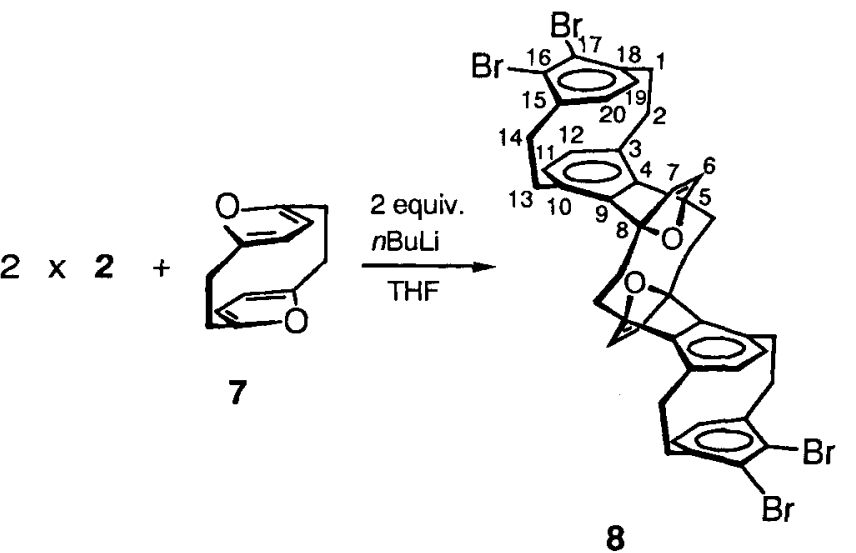

As demonstrated with the preparation of $\mathbf{4}$ and $\mathbf{5}$, this new procedure offers a short and flexible access to anti[2.2] arenophanes in only three steps from commercially available [2.2]paracyclophane.

Solutions of the anthracenophane 5 show intense fluorescence. Upon comparison of the UV/Vis and fluorescence spectra of 5 with those of 9,10-diphenylanthracene (DPA) ${ }^{[13]}$ a loss of the fine structure is noticeable (see Figure 2). Corresponding maxima of the long-wave absorption band of 5 reveal a bathochromic shift of $17-21 \mathrm{~nm}$ with respect to

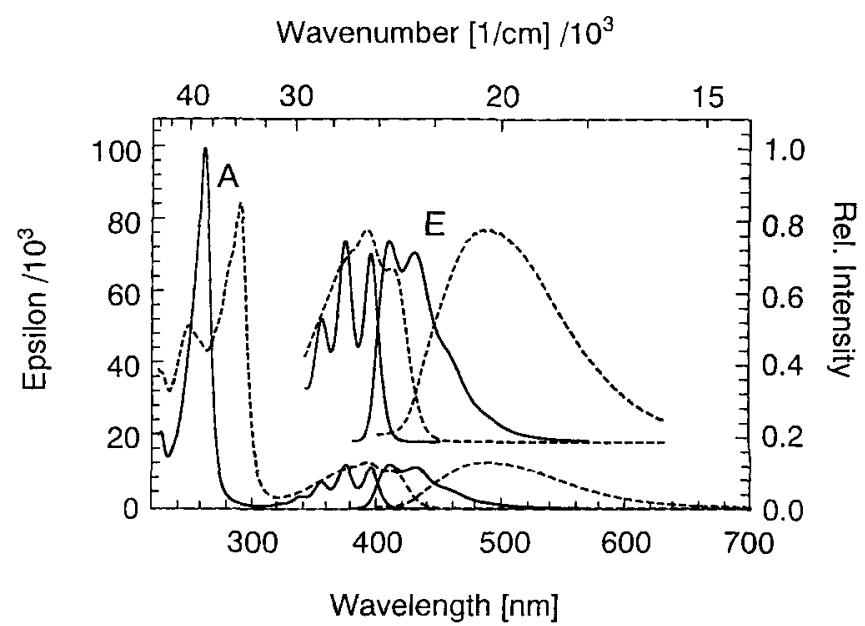

Figure 2. Electronic absorption (A) and emission (E) spectra of 9,10diphenylanthracene $(-$, excitation at $\lambda=356 \mathrm{~nm})$ and $9,9^{\prime}, 10,10^{\prime}-$ tetraphenyl-anti-[2.2](1,4)anthracenophane (5) $(---$, excitation at $\lambda=392 \mathrm{~nm})$ 
DPA which is due mainly to the 1,4-dialkyl substitution of the phanaromatic units, whereas the emission band of 5 shows a shift of $65 \mathrm{~nm}$ when compared with the center of the two maxima of DPA. This increase, even when calculated in wave numbers (1100 to $3200 \mathrm{~cm}^{-1}$ approx.), and the broadening of the band suggest that excimer fluorescence contributes to the emission spectrum of 5 .

This work was supported by the Volkswagen-Stiftung and the Fonds der Chemischen Industrie. We are grateful to BASF, Hoechst, Bayer, and Degussa $A G$ for generous gifts of chemicals. B. Kö. is indebted to the Studienstiftung des Deutschen Volkes for a graduate fellowship (Promotionsstipendium).

\section{Experimental}

IR: Perkin-Elmer 125, 297, and 399. - UV: Varian Cary 219. Fluorescence: Perkin-Elmer MPF-44A. $-{ }^{1} \mathrm{H},{ }^{13} \mathrm{C}$ NMR: Bruker WM 250 and AW 400; the multiplicity of the ${ }^{13} \mathrm{C}$-NMR signals was determined with the DEPT technique by using a last pulse angle of $135^{\circ}$. - EI/MS (70 eV): Varian MAT CH7, VG-70-250S (VG Analytical). - PE: Petroleum ether (boiling range $60-70^{\circ} \mathrm{C}$ ).

General Procedure for the Generation of the Bis(aryne) from 4,5,12,13-Tetrabromo [2.2] paracyclophane (2) ${ }^{[2]}$ (GP 1): To a mixture of $1.0 \mathrm{mmol}$ of 2 and the stated amount of diene in $80 \mathrm{ml}$ of THF was added dropwise at $-40^{\circ} \mathrm{C} 2.2 \mathrm{mmol}$ of $n \mathrm{BuLi}$, further diluted with $15 \mathrm{ml}$ of hexane, over a period of $1 \mathrm{~h}$. The mixture was allowed to warm up to room temp., then $2 \mathrm{ml}$ of methanol and $50 \mathrm{ml}$ of diethyl ether were added, and the mixture was washed with water $(3 \times 50 \mathrm{ml})$. The organic layer was dried with $\mathrm{K}_{2} \mathrm{CO}_{3}$, filtered, concentrated in vacuo, and the residue was chromatographed on silica gel.

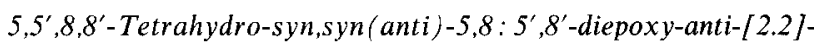
$(1,4)$ naphthalenophane $(3): 524 \mathrm{mg}(1.00 \mathrm{mmol})$ of 2 and $3.00 \mathrm{ml}$ $(31.0 \mathrm{mmol})$ of furan were allowed to react according to GP 1 . The crude reaction product (162 $\mathrm{mg} ; 47 \%$ ) was chromatographed on $50 \mathrm{~g}$ of silica gel $\left[\mathrm{CH}_{2} \mathrm{Cl}_{2} / \mathrm{PE}(1: 1)\right]$ to yield fraction $\mathrm{I}\left(\boldsymbol{R}_{\mathrm{f}}=0.35\right.$, $\left.\mathrm{CH}_{2} \mathrm{Cl}_{2}\right): 41 \mathrm{mg}(12 \%)$ of syn,syn-3. - ${ }^{1} \mathrm{H} \mathrm{NMR}\left(250 \mathrm{MHz}, \mathrm{CDCl}_{3}\right)$ : $\delta=3.05(\mathrm{~m}, 8 \mathrm{H}), 5.58\left[\mathrm{~s}, 4 \mathrm{H}, 5\left(5^{\prime}, 8,8^{\prime}\right)-\mathrm{H}\right], 6.08[\mathrm{~s}, 4 \mathrm{H}, 11-$ $\left.\left(11^{\prime}, 12,12^{\prime}\right)-\mathrm{H}\right], 6.90\left[\mathrm{~s}, 4 \mathrm{H}, 6\left(6^{\prime}, 7,7^{\prime}\right)-\mathrm{H}\right] .-{ }^{13} \mathrm{C}$ NMR $(62.5 \mathrm{MHz}$, $\left.\mathrm{CDCl}_{3}\right): \delta=31.26(-), 80.81(+), 130.95(+), 131.65\left(\mathrm{C}_{\text {quat }}\right), 143.28$ $(+), 147.82\left(\mathrm{C}_{\text {quat }}\right) .-\mathrm{II}\left(R_{\mathrm{f}}=0.2, \mathrm{CH}_{2} \mathrm{Cl}_{2}\right): 51 \mathrm{mg}(15 \%)$ of anti,syn3. $-{ }^{1} \mathrm{H}$ NMR $\left(250 \mathrm{MHz}, \mathrm{CDCl}_{3}\right): \delta=2.60-3.20(\mathrm{~m}, 8 \mathrm{H}), 5.41$ (s, $2 \mathrm{H}), 5.52$ and $5.59(\mathrm{~s}, 4 \mathrm{H}), 6.00(\mathrm{~s}, 2 \mathrm{H}), 6.83$ and $7.10(\mathrm{~s}, 4 \mathrm{H})$. ${ }^{13} \mathrm{C}$ NMR $\left(62.5 \mathrm{MHz}, \mathrm{CDCl}_{3}\right): \delta=31.33$ and $31.60(-), 80.71$ and $80.93(+), 128.57$ and $130.43(+), 131.23$ and $132.10\left(\mathrm{C}_{\text {quat }}\right), 140.12$ and $143.12(+), 145.42$ and $148.80\left(\mathrm{C}_{\text {quat }}\right)$. - MS, $m / z(\%): 340(50)$ $\left[\mathrm{M}^{+}\right], 170(100)\left[\mathrm{M}^{2+}\right]$.

$X$-Ray Structure Analysis of syn,syn-3 ${ }^{[14]}$ : Diffractometer Stoe AED2, Mo- $K_{\alpha}$ radiation $(\lambda=0.71073 \AA$ ), graphite monochromator, direct methods, refinement by full-matrix least squares of $F^{2}$ (SHELXL-92) ${ }^{[15]} \cdot \mathrm{C}_{24} \mathrm{H}_{20} \mathrm{O}_{2}, 340.4 \mathrm{~g} \mathrm{~mol}^{-1}$. Triclinic crystals, crystal dimensions $0.50 \times 0.50 \times 0.20 \mathrm{~mm}$, space group $P \overline{1}, Z=2$; unit cell dimensions: $a=913.5(1), b=983.9(1), c=988.4(1) \mathrm{pm}, \alpha=$ 84.91(1), $\beta=85.97(1), \gamma=72.76(1)^{\circ}, V=0.8442(2) \mathrm{nm}^{3}, \varrho_{\text {calcd. }}=1.339$ $\mathrm{g} \mathrm{cm}^{-3}, 2197$ observed reflections (all independent) with $2 \Theta<45^{\circ}$, $I>2 \sigma(I), R=0.055, w R 2=0.1207^{[7]}$. Selected bond lengths [pm] and angles $\left[{ }^{\circ}\right]$ : $\mathrm{C}(1)-\mathrm{C}(10)$ 150.5(5), $\mathrm{C}(1)-\mathrm{C}(2)$ 156.3(6), $\mathrm{C}(2)-\mathrm{C}(3)$ 150.8(5), C(3)-C(4) 138.2(5), C(3)-C(12) 139.7(5), C(4)-C(9) 140.8(5), $\mathrm{C}(4)-\mathrm{C}(5) \quad 151.9(5), \quad \mathrm{C}(5)-\mathrm{O}(51) \quad 144.5(5), \quad \mathrm{C}(5)-\mathrm{C}(6) \quad 152.7(6)$, $\mathrm{O}(51)-\mathrm{C}(8)$ 144.1(4), $\mathrm{C}(6)-\mathrm{C}(7)$ 131.9(6), C(11)-C(12) 137.0(5); $\mathrm{C}(10)-\mathrm{C}(1)-\mathrm{C}(2) \quad 113.8(3), \mathrm{C}(3)-\mathrm{C}(2)-\mathrm{C}(1) \quad 112.8(3), \mathrm{C}(4)-\mathrm{C}(3)-$
$\mathrm{C}(12) 114.7(3), \mathrm{C}(4)-\mathrm{C}(3)-\mathrm{C}(2) 123.6(3), \mathrm{C}(12)-\mathrm{C}(3)-\mathrm{C}(2) 120.0(3)$, $\mathrm{C}(3)-\mathrm{C}(4)-\mathrm{C}(9)$ 121.7(3), C(3)-C(4)-C(5) 133.6(3), C(9)-C(4)-C(5) 103.5(3), $\mathrm{O}(51)-\mathrm{C}(5)-\mathrm{C}(4) 101.1(3), \mathrm{O}(51)-\mathrm{C}(5)-\mathrm{C}(6) 100.1(3), \mathrm{C}(4)-$ $\mathrm{C}(5)-\mathrm{C}(6) \quad 106.2(3), \quad \mathrm{C}(8)-\mathrm{O}(51)-\mathrm{C}(5) \quad 95.0(3), \quad \mathrm{C}(7)-\mathrm{C}(6)-\mathrm{C}(5)$ 105.5(4).

anti-[2.2](1,4) Naphthalenophane (4): $2.40 \mathrm{ml}(22.0 \mathrm{mmol})$ of titanium tetrachloride and $0.53 \mathrm{~g}(0.70 \mathrm{ml}, 5.20 \mathrm{mmol})$ of triethylamine were added under $\mathrm{N}_{2}$ to a cold suspension of $370 \mathrm{mg}(9.70$ mmol) of $\mathrm{LiAlH}_{4}$ in $80 \mathrm{ml}$ of THF, and the mixture was refluxed for $30 \mathrm{~min}$. After cooling to room temp., $200 \mathrm{mg}(0.59 \mathrm{mmol})$ of syn,syn (anti)-3 was added in $30 \mathrm{ml}$ of THF, and the mixture was stirred for $4 \mathrm{~h}$. Then, excess $\mathrm{LiAlH}_{4}$ was hydrolyzed by the addition of ice/water $(100 \mathrm{ml})$, the mixture was diluted with $200 \mathrm{ml}$ of $\mathrm{CH}_{2} \mathrm{Cl}_{2}$, and the organic phase washed with water $(2 \times 100 \mathrm{ml})$, dried with $\mathrm{MgSO}_{4}$, filtered and concentrated in vacuo. Chromatography of the residue on silica gel $\left[\mathrm{CH}_{2} \mathrm{Cl}_{2} / \mathrm{PE}(1: 1)\right]$ yielded $125 \mathrm{mg}(69 \%)$ of 4 $\left(R_{\mathrm{f}}=0.6\right)$. All spectroscopic data agree with the reported ones ${ }^{[10]}$.

$9,9^{\prime}, 10,10^{\prime}$-Tetraphenyl-anti-[2.2](1,4)anthracenophane (5): 524 $\mathrm{mg}(1.00 \mathrm{mmol})$ of 2 and $810 \mathrm{mg}(3.00 \mathrm{mmol})$ of 2,4-diphenylisobenzofuran were allowed to react according to GP 1 . The crude product was chromatographed on $80 \mathrm{~g}$ of silica gel $\left[1 . \mathrm{CH}_{2} \mathrm{Cl}_{2} / \mathrm{PE}\right.$ (1:1), 2. $\left.\mathrm{CH}_{2} \mathrm{Cl}_{2}\right]$. - Fraction I $\left(R_{\mathrm{f}}=0.9, \mathrm{CH}_{2} \mathrm{Cl}_{2}\right):$ 2,4-diphenylisobenzofuran, not isolated. - II $\left(R_{\mathrm{f}}=0.64, \mathrm{CH}_{2} \mathrm{Cl}_{2}\right): 190 \mathrm{mg}(25 \%)$

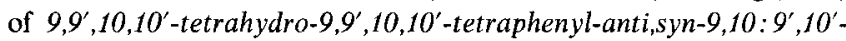
diepoxy-anti-[2.2] $(1,4)$ anthracenophane, white solid, m.p. $>280^{\circ} \mathrm{C}$ - ${ }^{1} \mathrm{H}$ NMR (250 MHz, $\left.\mathrm{CDCl}_{3}\right): \delta=2.05-2.40$ and $2.83(\mathrm{~m}, 8 \mathrm{H})$, $4.58(\mathrm{~s}, 2 \mathrm{H}), 6.25(\mathrm{~s}, 2 \mathrm{H}), 6.91$ and $7.22(\mathrm{~m}, 4 \mathrm{H}), 7.30-7.70(\mathrm{~m}, 16 \mathrm{H})$, 7.82 and $8.12(\mathrm{~m}, 8 \mathrm{H})$. - MS, $m / z(\%): 744(41)\left[\mathrm{M}^{+}\right], 105(100)$. - III $\left(R_{\mathrm{f}}=0.46, \mathrm{CH}_{2} \mathrm{Cl}_{2}\right): 242 \mathrm{mg}(33 \%)$ of $9,9^{\prime}, 10,10^{\prime}$-tetrahydro-

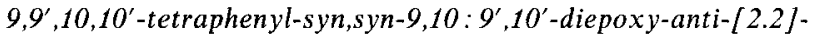

(1,4) anthracenophane, m.p. $>280^{\circ} \mathrm{C}$ - ${ }^{1} \mathrm{H}$ NMR $(250 \mathrm{MHz}$, $\left.\mathrm{CDCl}_{3}\right): \delta=2.45$ and $2.80(\mathrm{~m}, 8 \mathrm{H}), 4.70$ and $6.20(\mathrm{~s}, 4 \mathrm{H}), 6.90(\mathrm{~m}$, $2 \mathrm{H}), 7.30-7.65(\mathrm{~m}, 18 \mathrm{H}), 7.85$ and $8.08(\mathrm{~m}, 8 \mathrm{H})$. $-\mathrm{MS}, \mathrm{m} / \mathrm{z}(\%)$ : $744(65)\left[\mathrm{M}^{+}\right], 105(100)$. - To a mixture of $30 \mathrm{mg}(0.04 \mathrm{mmol})$ of the Diels-Alder products and $166 \mathrm{mg}(1.00 \mathrm{mmol})$ of potassium iodide in $12 \mathrm{ml}$ of acetonitrile was added $0.10 \mathrm{ml}(0.80 \mathrm{mmol})$ of trimethylsilyl chloride, and the reaction mixture was stirred at room temp. for $16 \mathrm{~h}$. The reaction was quenched by the addition of 20 $\mathrm{ml}$ of a satd. aqueous sodium thiosulfate solution. After dilution with $200 \mathrm{ml}$ of $\mathrm{CH}_{2} \mathrm{Cl}_{2}$, the organic phase was extracted with water $(2 \times 100 \mathrm{ml})$, dried with $\mathrm{MgSO}_{4}$, filtered and concentrated in vacuo. Chromatography of the residue on $50 \mathrm{~g}$ of silica gel $\left[\mathrm{CH}_{2} \mathrm{Cl}_{2} / \mathrm{PE}\right.$ $(1: 1)]$ yielded $16 \mathrm{mg}(55 \%)$ of 5 as a yellow solid, m.p. $>280^{\circ} \mathrm{C}$. Elemental analyses revealed a considerable amount of solvents $\left(\mathrm{CH}_{2} \mathrm{Cl}_{2}\right.$ and $\mathrm{PE}$, approx. $6 \mathrm{~mol}-\%$ each) enclosed in the crystals, which could not be removed by drying for $6 \mathrm{~d} / 0.1$ Torr and may account for the relatively low extinction coefficients observed for the two independent chromophores in 5 as compared to the one in 9,10-diphenylanthracene (cf. Figure 2). - IR (KBr): $\tilde{v}=2919 \mathrm{~cm}^{-1}$, 1016, 764, 701. - UV $\left(\mathrm{CH}_{2} \mathrm{Cl}_{2}\right): \lambda_{\max }(\lg \varepsilon)=412 \mathrm{~nm}$ (4.03), 392 (4.11), 377 (4.06 sh), 290 (4.93), 249 (4.71). - Fluorescence $\left(\mathrm{CH}_{2} \mathrm{Cl}_{2}\right.$, excitation at $392 \mathrm{~nm}): \lambda_{\max }=486 \mathrm{~nm}$. $-{ }^{1} \mathrm{H}$ NMR $(250 \mathrm{MHz}$, $\left.\mathrm{CDCl}_{3}\right): \delta=1.65$ and $2.30(\mathrm{~m}, 8 \mathrm{H}), 5.79(\mathrm{~s}, 4 \mathrm{H}), 7.01(\mathrm{~m}, 4 \mathrm{H})$, $7.25-7.60(\mathrm{~m}, 16 \mathrm{H}), 7.72(\mathrm{~m}, 4 \mathrm{H}), 7.91(\mathrm{~m}, 4 \mathrm{H}) .-{ }^{13} \mathrm{C}$ NMR $(62.5$ $\left.\mathrm{MHz}, \mathrm{CDCl}_{3}\right): \delta=37.20(-), 124.63,126.47,127.05,127.24,128.65$ and $129.65(+), 131.02\left(\mathrm{C}_{\text {quat }}\right), 131.09$ and $131.44(+), 133.25,136.08$, 137.45, and $142.08\left(\mathrm{C}_{\text {quat }}\right)$. - MS, $m / z(\%): 712(18)\left[\mathrm{M}^{+}\right], 356(100)$ $\left[\mathrm{M}^{2+}\right]$. $-\mathrm{C}_{56} \mathrm{H}_{40}$ : calcd. for $\left[\mathrm{M}^{+}\right]$712.3130, found $712.3086(\mathrm{MS})$; calcd. for $\left[\mathrm{M}^{2+}\right] 356.1565$, found 356.1569 (MS). - If the reaction was stopped and worked up after a reaction time of $30 \mathrm{~min}$, $9,9^{\prime}, 10,10^{\prime}$-tetrahydro-9, $9^{\prime}, 10,10^{\prime}$-tetraphenyl-9,10-epoxy-anti- $[2]$ $(1,4)$ anthraceno 2$]\left(1^{\prime}, 4^{\prime}\right)$ anthracenophane was obtained in $69 \%$ yield. $-{ }^{1} \mathrm{H} \mathrm{NMR}\left(250 \mathrm{MHz}, \mathrm{CDCl}_{3}\right): \delta=1.35,1.55,2.20$, and 3.00 
$(\mathrm{m}, 8 \mathrm{H}), 5.38$ and $6.75(\mathrm{~s}, 4 \mathrm{H}), 6.85$ and $7.00(\mathrm{~m}, 4 \mathrm{H}), 7.20-7.90$ $(\mathrm{m}, 20 \mathrm{H}), 8.15(\mathrm{~m}, 4 \mathrm{H}) .-{ }^{13} \mathrm{C}$ NMR $\left(62.5 \mathrm{MHz}, \mathrm{CDCl}_{3}\right): \delta=34.01$ and $36.92(-), 90.28\left(\mathrm{C}_{\text {quat }}\right), 119.63,124.74,125.29,126.58,127.09$, $127.18,127.29,127.97,128.03,128.72,129.80,131.64,131.73,131.85$, and $132.99(+), 133.79,135.34,136.88,137.18,141.96,146.87$, and $150.80\left(\mathrm{C}_{\text {quat }}\right)$. - MS, $m / z(\%): 728(49)\left[\mathrm{M}^{+}\right], 355(100)$.

$5,5^{\prime}, 8,8^{\prime}$-Tetrahydro-syn,syn(anti)-5,8:5'8'-bis(methano)-anti[2.2] (1,4) naphthalenophane (6): $524 \mathrm{mg}(1.00 \mathrm{mmol})$ of 2 and 0.40 $\mathrm{ml}(6.00 \mathrm{mmol})$ of cyclopentadiene were allowed to react according to GP 1. Chromatography of the crude product on $50 \mathrm{~g}$ of silica gel (PE) yielded $151 \mathrm{mg}(45 \%)$ of syn,syn (anti)-6. - ${ }^{1} \mathrm{H}$ NMR (250 $\left.\mathrm{MHz} \mathrm{CDCl}_{3}\right): \delta=0.91,1.65,2.15$, and $2.31(\mathrm{~m}, 8 \mathrm{H}), 3.00(\mathrm{~m}, 16 \mathrm{H})$, $3.86(\mathrm{~m}, 8 \mathrm{H}), 5.37$ and $5.82(\mathrm{~m}, 8 \mathrm{H}), 6.72$ and $6.92(\mathrm{~m}, 8 \mathrm{H}) .-{ }^{13} \mathrm{C}$ NMR (62.5 MHz, $\left.\mathrm{CDCl}_{3}\right): \delta=31.11,31.39$, and $31.50(-), 47.59$, $47.75,47.92$, and $48.11(+), 67.52,67.62,68.28$, and $68.46(-)$, 127.96, 128.13, and $128.16(+), 131.03,132.02,132.20$, and 133.12 $\left(\mathrm{C}_{\text {quat }}\right), 139.28$ and $139.51(+), 144.28$ and $144.41(+), 147.87,148.12$, and $149.66\left(\mathrm{C}_{\text {quat }}\right)$.

Cyclophane 8: To a mixture of $100 \mathrm{mg}(0.53 \mathrm{mmol})$ of 7 and 613 $\mathrm{mg}(1.30 \mathrm{mmol})$ of $2 \mathrm{in} 80 \mathrm{ml}$ of THF at $-90^{\circ} \mathrm{C}$ was added dropwise $0.90 \mathrm{ml}(1.30 \mathrm{mmol})$ of $n \mathrm{BuLi}(1.4 \mathrm{M}$ in hexane $)$ in $10 \mathrm{ml}$ of hexane. The reaction mixture was allowed to warm up to room temp. during $12 \mathrm{~h}$, then $2 \mathrm{ml}$ of methanol and $200 \mathrm{ml}$ of $\mathrm{CH}_{2} \mathrm{Cl}_{2}$ were added, the organic phase was washed with water $(3 \times 50 \mathrm{ml})$, dried with $\mathrm{Na}_{2} \mathrm{SO}_{4}$, filtered and concentrated in vacuo. Chromatography of the residue on $100 \mathrm{~g}$ of silica gel $\left[\mathrm{CH}_{2} \mathrm{Cl}_{2} / \mathrm{PE}(1: 1)\right]$ yielded $145 \mathrm{mg}$ $(30 \%)$ of $8\left(R_{\mathrm{f}}=0.23\right)$. $\quad-{ }^{1} \mathrm{H}$ NMR $\left(250 \mathrm{MHz}, \mathrm{CDCl}_{3}\right)$ : $\delta=2.25-3.10(\mathrm{~m}, 24 \mathrm{H}), 5.60(\mathrm{~s}, 4 \mathrm{H}), 6.10(\mathrm{~s}, 4 \mathrm{H}), 6.60(\mathrm{~s}, 4 \mathrm{H})$. ${ }^{13} \mathrm{C} \mathrm{NMR}\left(62.5 \mathrm{MHz}, \mathrm{CDCl}_{3}\right): \delta=25.89,32.19$, and $34.34(-), 90.53$ $\left(C_{\text {quat }}\right), 111.34(+), 111.55$ and $129.68\left(C_{\text {qual }}\right), 130.76$ and $143.45(+)$, 153.14 and $160.14\left(\mathrm{C}_{\text {qual }}\right)$.

[1] [1a] H. Hart, G. C. Nwokogu, Tetrahedron Lett. 1983, 24, 5721-5724. - ${ }^{[16]}$ H. Hart, A. Sy, J. Org. Chem. 1979, 44,
7-9. $-{ }^{[1 c]}$ H. Hart, C. Y. Lai, J. Am. Chem. Soc. 1980, 102, $6649-6651$

${ }^{[2]}$ B. König, B. Knieriem, A. de Meijere, Chem. Ber. 1993, 126, $1643-1650$.

${ }^{[3]}$ H. Hope, J. Bernstein, N. K. Trueblood, Acta Crystallogr., Sect. $B, 1972,28,1733-1743$.

${ }^{[4]}$ H. Hart, C. Y. Lai, G. C. Nwokogu, S. Shumonilian, Tetrahedron $1987,43,5203-5224$.

[5] The first dehydroarene of [2.2]paracyclophane has been generated by dehydrobromination of 4-bromo[2.2]paracyclophane: D. T. Longone, G. R. Chipman, Chem. Commun. 1969, $1358-1359$

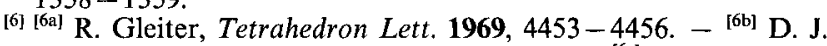
Cram, Acc. Chem. Res. 1971, 4, 204-213. - ${ }^{[6 c]}$ Cf. also: P. H. Kuhn, S. H. Rosenfeld, Cyclophanes, Academic Press, New York, 1983, vol. 1 and 2. - ${ }^{[6 \mathrm{~d}]}$ F. Vögtle, Top. Curr. Chem. $1983,113,1-183 ; 1983,115,1-159$, and references cited therein.

${ }^{[7]}$ Further details of the crystal structure investigation are available on request from the Fachinformationszentrum Karlsruhe, Gesellschaft für wissenschaftlich-technische Information $\mathrm{mbH}$, D-76344 Eggenstein-Leopoldshafen, on quoting the depository number CSD-57201, the names of the authors, and the journal citation.

${ }^{[8]}$ Cf:: V. Boekelheide, Top. Curr. Chem. 1983, 113, 87-143, and references cited therein.

${ }^{19]}$ H. Hart, G. C. Nwokogu, J. Org. Chem. 1981, 46, 1251- 1255.

${ }^{[10]}$ D. J. Cram, K. Dalton, G. Knox, J. Am. Chem. Soc. 1963, 85, $1088-1093$.

[11] Cf.: J. Koreeda, K. Jung, J. Org. Chem. 1989, 54, 5667-5675.

${ }^{[12]}{ }^{[12 a]}$ H. E. Winberg, F. S. Fawcett, W. E. Mochel, C. W. Theobald, J. Am. Chem. Soc. 1960, 82, 1428-1435. - ${ }^{[12 b]}$ R. F. Holdren, R. M. Hixon, J. Am. Chem. Soc. 1946, 68, 1198-1200. ${ }_{[12 . c]}$ L. A. Paquette, H. Berk, R. Moerck, J. Am. Chem. Soc. 1978 $100,5845-5855$.

[13] UV Atlas Organischer Verbindungen, VCH, Weinheim, 1966, vol. I, E2/5; I. B. Berlman, Handbook of Fluorescence Spectra of Aromatic Molecules, Academic Press, New York, 1965, p. 130.

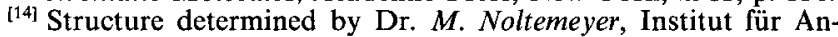
organische Chemie, Göttingen.

${ }^{[15]}$ G. M. Sheldrick, J. Appl. Cryst., manuscript in preparation.

[108/93] 